\title{
Energy and exergy analysis of a centrifugal pump driven by a diesel engine operating with passion fruit biodiesel and mixtures with diesel
}

The present study is related with the analysis of energy and exergy of a centrifugal pump driven by a single cylinder diesel engine operating with passion fruit biodiesel and mixtures with diesel. Values of the useful work, the reversible work and the efficiency of the second law of thermodynamics were obtained. The passion fruit oil used to obtain the biodiesel was produced by mechanical extraction, filtration and degumming process from seeds discarded from the production process of passion fruit juice. The passion fruit biodiesel was produced by transesterification using ultrasound and methanol in the proportion of $40 \% \mathrm{v} / \mathrm{v}$ with a $1 \%$ of $\mathrm{NaOH}$ as a catalyst. The passion fruit biodiesel-diesel mixtures were prepared and classified as B0, B25, B50, B75 and B100. These mixtures were submitted to physical-chemical characterization and utilized in the centrifugal pump driven by a diesel engine. For the mixtures of passion fruit biodiesel with diesel, the maximum efficiency of the second law was $29.83 \%$ in the case of B25 mixture, at $9.45 \mathrm{~m} 3 / \mathrm{h}$ and at maximum pump speed. When the centrifugal pump operated at maximum flow rate, the maximum efficiency of the second law was $31.78 \%$ in the case of passion fruit biodiesel (B100), at $2722 \mathrm{rpm}$.

Keywords: Passion Fruit Biodiesel; Centrifugal Pump; Energy; Exergy; Sustainability.

\section{Análise de energia e exergia de uma bomba centrífuga acionada por um motor diesel operando com biodiesel de maracujá e misturas com diesel}

\begin{abstract}
O presente estudo está relacionado com a análise de energia e exergia de uma bomba centrífuga acionada por um motor diesel monocilíndrico operando com biodiesel de maracujá e misturas com diesel. Valores do trabalho útil, do trabalho reversível e da eficiência da segunda lei da termodinâmica foram obtidos. O óleo de maracujá utilizado para obtenção do biodiesel foi produzido por extração mecânica, filtração e processo de degomagem a partir de sementes descartadas do processo de produção do suco de maracujá. O biodiesel de maracujá foi produzido por transesterificação utilizando ultrassom e metanol na proporção de $40 \%$ v v com $1 \%$ de $\mathrm{NaOH}$ como catalisador. As misturas biodiesel-diesel de maracujá foram preparadas e classificadas como B0, B25, B50, B75 e B100. Essas misturas foram submetidas à caracterização físico-química e utilizadas na bomba centrífuga acionada por um motor a diesel. Para as misturas de biodiesel de maracujá com diesel, a eficiência máxima da segunda lei foi de $29,83 \%$ no caso da mistura B25, a 9,45 m3/h e na velocidade máxima da bomba. Quando a bomba centrífuga operou na vazão máxima, a eficiência máxima da segunda lei foi de 31,78\% no caso do biodiesel de maracujá (B100), a 2722 rpm.
\end{abstract}

Palavras-chave: Biodiesel de Maracujá; Bomba Centrífuga; Energia; Exergia; Sustentabilidade.

Topic: Desenvolvimento, Sustentabilidade e Meio Ambiente

Reviewed anonymously in the process of blind peer.
Received: 02/12/2018

Approved: 26/01/2019
Roberto Pereira (D)

Universidade Federal Fluminense, Brasil http://orcid.org/0000-0001-6094-1396 temrobe@vm.uff.br

Ivenio Moreira da Silva (iD

Universidade Federal Fluminense, Brasil

http://lattes.cnpq.br/8851564731097828

http://orcid.org/0000-0003-0776-7565

ivenio@vm.uff.br
Referencing this:

PEREIRA, R.; SILVA, I. M.. Energy and exergy analysis of a centrifugal pump driven by a diesel engine operating with passion fruit biodiesel and mixtures with diesel. Revista Ibero Americana de Ciências Ambientais, v.10, n.1, p.262-273, 2019. DOI:

http://doi.org/10.6008/CBPC2179-6858.2019.001.0022 


\section{INTRODUCTION}

The energetics alternatives derived from biomass emerges as considerable options for replace fossil fuels. Biodiesel is an alternative fuel to the common diesel oil, being derived from renewable sources as, for example, soybeans, palm, coconut, castor bean, cotton, sunflower, tallow etc. This biofuel has physical, chemical and rheological properties like diesel and can be used in conventional engines (PEREIRA et al., 2017a; 2017b; 2014; 2012; 2007; ARRUDA et al., 2017; ATABANI et al., 2014; DEMIRBAS, 2009). The combustion of biodiesel in diesel engines generates a reduction in the emission of pollutant gases: sulfur oxides; hydrocarbons; carbon monoxide and particulate matter. Furthermore, studies have shown that biodiesel promotes the recycling of $\mathrm{CO}_{2}$ and is an excellent lubricant which can increase engine life.

According to Festel et al. (2014) the future evolution of biofuel production costs' in Europe was investigated considering the effects of the technological learning and production scale. In that study it was observed that in the short and medium term, the second-generation biodiesel from residual oil, and palm oil are the most promising as production costs.

Solis et al. (2017) pointed out that even though vegetable oil production is increasing, the driving force towards eco-friendly biofuels has changed the attention towards second and third generation feedstocks (non-edible oils, waste cooking oil, animal fats and algae). All the diesel engines are widely used in various steps in the agribusiness chain. On a farm, diesel engines enable activities both in fixed locations and in other situations that require mobility.

The supply of water for irrigation takes place, especially with the use of centrifuges pumps that can be triggered either by electric motors or by Otto cycle motors or Diesel cycle motors. Generally, the pump is installed in an area near the water reservoir avoiding problems in the suction system. To this end, the costs to adapt the electrical network can unfeasible the project. An appropriate alternative is to trigger the system by means of a diesel engine, which provides mobility and can operate in more than one location serviced by other reservoirs.

The irrigation of cultivated areas can be seen in many regions as unfeasible by the high cost of equipment and limitations on availability of electric energy. However, it is possible to run an irrigation system using a set mobile pump with diesel drive. The integrated pumps sets can be used in water supply for irrigation and for various other applications in farms or rural communities. The demands to be met vary from small areas to those that include major extensions.

Thus, the purpose of the present study was to obtain the biodiesel through the oil extracted from seeds of passion fruit, to prepare the mixtures of biodiesel with diesel, to use them in a centrifugal pump driven by a single cylinder diesel engine coupled at an instrumentalized hydraulic circuit and to realize the energetic and exergetic analysis of the system. It is important to emphasize that the passion fruit biodiesel used in the tests was produced from oil extracted from discarded seeds, becoming an alternative of economic interest for the biodiesel production. 


\section{THEORETICAL REVIEW}

\section{Passion Fruit}

The Passion fruit (Passiflora edulis) is native from Tropical America and is a very cultivated fruit in Brazil. It is rich in vitamin C, calcium and phosphorus. The greatest economic importance of passion fruit is in the industrialized product in the form of concentrated juice. Brazil stands out as the main producer of passion fruit in the world. In 2016, Brazil produced 703,489 t, with a yield of 14.10 t/ha (KIST et al., 2018). The oil extracted from discarded seeds can become an alternative of economic interest destined to the production of cosmetics as well as other industrial applications, besides the use as raw material to produce biodiesel.

\section{Energy Analysis}

A conventional thermodynamic analysis involves an application of the first law of thermodynamics, also known as energy analysis. The first law of thermodynamics, also known as the conservation of energy principle, provides a sound basis for studying the relationships among the various forms of energy and energy interactions. The first law is concerned with the quantity of energy and the transformations of energy from one form to another with no regard to its quality (KANOĞLU et al., 2012).

When sizing and recommend the use of internal combustion engines to drive hydraulic pumps, generally the attention is to usual procedures, which include the calculation of the pressure drop in the pipe and sizing of the power required to overcome such losses and to trigger the system. The capacity of the pump in convert the energy provided by the fuel into work constitutes an important aspect on thermodynamic point of view, considering the amount of energy and energy conversion capacity.

\section{Exergy Analysis}

Exergy analysis is a thermodynamic analysis technique based on the second law of thermodynamics that provides an alternative of assessing and comparing processes and systems rationally and meaningfully. The use of the second law of thermodynamics is not limited to identifying the direction of processes. The second law also asserts that energy has quality as well as quantity. Preserving the quality of energy is of major concern to engineers, and the second law provides the necessary means to determine the quality as well as the degree of degradation of energy during a process (KANOĞLU et al., 2012).

Some articles related with the exergy analysis are presented below. It was used the exergy analysis as an environmental assessment tool to account waste and emissions, comparing substitutes and other types of energy sources (TALENS et al., 2007). The methodology was developed in steps: establishment of system limits by drawing the diagram of industrial process flow under study, determination of which inputs/outputs steps and byproducts makes part of the system. Definition of the system limits and process division into operating units for the study of each limit from an independently form. The exergy flow analysis provides a way for the evaluation of the process which can be used as an identification tool of waste materials and energy loss, detecting the areas that need improvement. Exergy is also a useful indicator of measurement of 
potential material reactivity and quality, comparing different production processes and products of substitution, which is especially useful for comparing renewable energy sources.

Reifarth et at. (2015) studied the exhaust gas recirculation (EGR) in order that the emission legislation for internal combustion engines has become increasingly more rigorous. At that time were compared methods of energy and exergy analysis used in gas exchange system analysis, attesting to the importance of the information presented in exergy analysis.

Flórez-Orrego et al. (2014) used the exergy as a rational base to compare the performance of the electricity generation processes using the different energy sources the Brazilian electricity mix is composed of. An exergoeconomic assessment accounting for the total and non-renewable unit exergy costs and specific $\mathrm{CO}_{2}$ emissions of Brazilian electricity, based on the national electric mix and the representative profiles of electricity generation routes, is performed. This approach allows the calculation of direct $\mathrm{CO}_{2}$ emissions of the power plant as well as the upstream and downstream fuel processing-related indirect emissions, which play a much more important role in technologies different from fossil-fired power plants.

Features of energy and exergetic performance combined in a heat exchanger were studied by Tiwari et al. (2014). This study revealed that the heat loss has significant contribution on the irreversibility and both heat capacity and effectiveness affects the exergetic efficiency. Punov et al. (2017) showed a brief review of thermal engines designed for terrestrial transportation since the 1900s. The general concept of high-energy performance machines is analyzed from the energy, exergy, and public health point of view. Whereas the energy analysis revealed high potential of waste heat recovery from both exhaust and cooling system, the exergetic analysis revealed much higher recovery potential from exhaust gases. The exergy content of exhaust gases was observed to be within the range from $10.4 \%$ to $20.2 \%$ of the fuel energy. The cooling exergy is within the range from $1.2 \%$ to $3.4 \%$ of the fuel energy.

The exergetical analysis was effectuated by Peiró et al. (2010), being compared the biodiesel production process from the frying oil to the rapeseed oil. In this study, the inputs and outputs of balance for the two raw materials were verified, being taken into consideration that the products had different life cycles, same price and tax break. It was found that the exergy inputs for frying oil and rapeseed oil biodiesel are $47.77 \mathrm{GJ} / \mathrm{t}$ e $77.05 \mathrm{GJ} / \mathrm{t}$, respectively. The main exergy input to the frying oil was the methanol (2.46GJ). Still in the rapeseed biodiesel production, the main exergy input were the synthetic fertilizers (8.78GJ), methanol (6.48GJ) and ethylene glycol (2.88GJ). It follows also that the methanol has a lower exergy in the production of the frying oil during the transesterification because almost the half of the input is retrieved and supplied in the process.

The behavior of a diesel engine running by means of biodiesel from olive pomace oil, diesel oil and mixtures was evaluated from the standpoint of exergy (LÓPEZ et al., 2014). The differences among diesel fuel become more evident when the amount of biodiesel in the blend increases. Based on these results, it can be concluded that olive-pomace oil biodiesel and its blends with diesel fuel may substitute the use of diesel fuel in compression ignition engines providing a renewable fuel with similar exergy efficiency and without any exergetic cost increment. 


\section{Energy and Exergy Analysis in a Centrifugal Pump Driven by a Diesel Engine}

Developed studies consider for the energy analysis a control volume that could cover the centrifugal pump driven by a diesel engine having, thus, input and output mass (MACEDO, 2013). It was based on the energy balance applied to a process for control volume (steady-flow process), expressed in the Equation 1:

$$
\dot{E}_{\text {in }}-\dot{E}_{\text {out }}=d E_{\text {system }} / d t=0
$$

Considering: steady state, uniform properties, single current; $\dot{Q}=0$ and negligible kinetic and potential energy variations, the useful work consumption $W_{u}$ (real) becomes a function of the difference of enthalpy between states 1 (initial, at the input of the pump) and 2 (final, at the output of the pump), according to Equation2:

$$
\dot{W}_{u}=\dot{m}\left(\mathrm{~h}_{2}-\mathrm{h}_{1}\right)
$$

Being the pump an adiabatic device, the term of exergy $\left(\mathrm{X}_{\text {heat }}\right)$ was despised. To obtain an expression for the reversible work $\left(\dot{W}_{\text {rev }}\right)$, the destroyed exergy ( $\left.X_{\text {destroyde }}\right)$ was made zero. Being the pump an adiabatic device, considering steady state and uniform properties the reversible work can be expressing in terms of the specific exergies according to Equation 3:

$$
\dot{W}_{\text {rev }}=\dot{\mathrm{m}}\left(\psi_{2}-\psi_{1}\right)
$$

In this case the work represents the minimum work consumed by the pump. Finally, the efficiency of Second Law $\left(\eta_{11}\right)$, for devices that consumes work, is the ratio between the minimum consumption of work (reversible work) and the useful work consumption (real work):

$$
\eta_{\| I}=\dot{W}_{\text {rev }} / \dot{W}_{u}=\left(\psi_{2}-\psi_{1}\right) /\left(\mathrm{h}_{2}-\mathrm{h}_{1}\right)
$$

\section{METHODOLOGY}

\section{Production and characterization of oil passion fruit and biodiesel}

The passion fruit oil and the passion fruit biodiesel were produced at the Thermo-Science Laboratory at Fluminense Federal University. The passion fruit oil used to obtain the biodiesel was produced by mechanical extraction, filtration and degumming process from seeds discarded from the production process of passion fruit juice.

The passion fruit seeds were obtained directly from the juice factory where are often seen as a byproduct in the juice industry. After being collected, the seeds were washed for the removal of the remains of fruit pulp and dried to be used as raw material in mechanical press to obtain the passion fruit oil. The passion fruit seeds were extracted in Ecirtec press, model MPE 40, with capacity to press $40 \mathrm{~kg} / \mathrm{h}$. The extracted oil was subsequently filtered on a paper filter.

In order to remove other impurities, present in the oil, such as phosphatides, an acid degumming using $5 \%$ phosphoric acid was done. The degumming was done fractionating the oil in volumes of $100 \mathrm{~mL}$, 
being heated in an oven at $65^{\circ} \mathrm{C}$. After that, $5 \mathrm{~mL}$ of phosphoric acid was measured in a $15 \mathrm{~mL}$ Becker. The heated oil was transferred to an Erlemeyer where the phosphoric acid was added and maintained under stirring for 30 minutes. Subsequently, the acid/oil mixture was transferred to a $500 \mathrm{~mL}$ decantation funnel, remaining for 24 hours to separation of impurities. The degummed oil was stored in amber glass bottles with capacity to one liter to be used in the biodiesel production.

The passion fruit biodiesel was produced by transesterification using ultrasound and methanol anhydrous PA $99.7 \%$ in the proportion of $40 \% \mathrm{v} / \mathrm{v}$ with a $1 \%$ of $\mathrm{NaOH}$ as a catalyst. The Cole Parmer (750W) ultrasound used was configured to effective action time of $20 \mathrm{~min}, 45^{\circ} \mathrm{C}$ temperature process and $35 \%$ of amplitude.

The biodiesel obtained was fractioned and mixed with diesel at the following's proportions in volume: diesel 100\%; biodiesel $25 \%$ and diesel $75 \%$; biodiesel $50 \%$ and diesel 50\%; biodiesel $75 \%$ and diesel 25\%; and biodiesel 100\%. These mixtures were denominated B0, B25, B50, B75 and B100, respectively, and they were conditioned in bottles of amber color. The mixtures were characterized, being determined: the kinematic viscosity (ASTM D 445); the density (ASTM D4052); cloud point (ASTM D2500); pour point (ASTM D97) and the higher heating value (ASTM D4809).

\section{Energy and exergy analysis}

Such analysis is based in the energy balance and in the efficiency of the Second Law of Thermodynamics, which is a measure of deviation that the pump presents from its ideal performance, once the real work of the pump $\left(W_{u}\right)$ will always be greater than its ideal work $\left(W_{\text {rev }}\right)$. For this case, the exergy analysis can be based on the measures of pressure and temperature at suction and at discharge of the fluid in the pump in operation, and room temperature. The Figure 1 shows the experimental apparatus used in the tests.

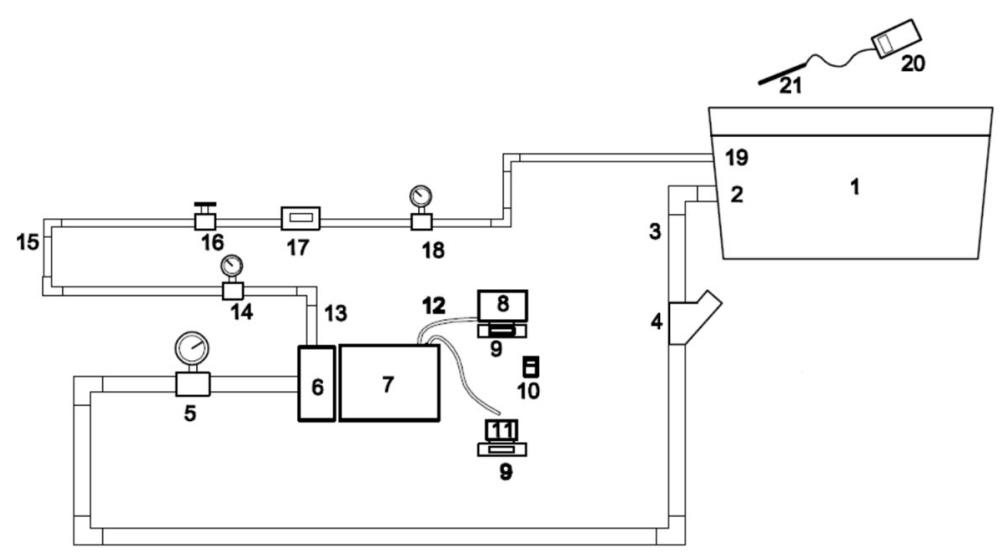

Figure 1 Experimental apparatus.

1 - reservoir; 2 - suction; 3 - tube of 2"; 4 - Y filter; 5 - pressure gauge in the suction; 6 - centrifugal pump; 7 - diesel engine; 8 - fuel reservoir; 9 - digital scale; 10 - room temperature meter; 11 - reservoir of returning fuel; 12 - hoses; 13 - discharge tube of 2"; 14 - pressure gauge (P.A.V.); 15 - tube of 1.5"; 16 - globe valve of 1.5"; 17 - flow meter; 18 pressure gauge (P.D.V.); 19 - discharge; 20- temperature meter; 21 - sensor

The diesel engine used has the following characteristics: Lintec manufacturer; $3300 \mathrm{rpm}$ higher speed; four-stroke; direct injection; one cylinder; air cooling system; $0.211 \mathrm{~L}$ displacement volume; $2.8 \mathrm{~kW}$ 
maximum output; $2.5 \mathrm{~L}$ fuel capacity and $32 \mathrm{~kg}$ weight. The centrifugal pump has the following characteristics: Lintec manufacturer; $36 \mathrm{~m}^{3} / \mathrm{h}$ maximum flow rate; $26 \mathrm{~m}$ maximum head; $8 \mathrm{~m}$ maximum suction head

\section{Pump at the maximum speed}

At the period that the motor was effectively working, it was registered the suction and the discharge temperatures of the centrifugal pump, the room temperature, the pressures at the manometer of suction and in the two manometers positioned before and after the globe valve that were restricted into six positions, with the pump at maximum speed (3300 rpm).

\section{Pump at the maximum flow rate}

In this case, the pump speed was changed, and the flow rate of the pump was kept at the maximum value (maximum opening of the globe valve). It was registered the suction and the discharge temperatures of the centrifugal pump, the room temperature, the pressures at the manometer of suction and in the two manometers positioned before and after the globe valve

\section{RESULTS AND DISCUSSION}

\section{Biodiesel production}

The average of the passion fruit biodiesel batches produced presented a yield of $75.69 \%$. It is understood that for being a process dependent of variables, such as temperature, catalyst and alcohol, the yield of the production of biodiesel can differ between authors. The founded value suggests an optimization of the process of biodiesel production.

\section{Properties of diesel, diesel-passion fruit biodiesel blends and passion fruit biodiesel}

Table 1 shows the properties of diesel, diesel-passion fruit biodiesel blends and passion fruit biodiesel.

Table 1: Properties of diesel, diesel-passion fruit biodiesel blends and passion fruit biodiesel.

\begin{tabular}{|l|l|l|l|l|l|}
\hline Properties & Diesel & B25 & B50 & B75 & B100 \\
\hline Viscosity at $40^{\circ} \mathrm{C}\left(\mathrm{mm}^{2} \cdot \mathrm{s}^{-1}\right)$ & 2.545 & 3.195 & 3.404 & 3.841 & 4.720 \\
\hline Density at $20^{\circ} \mathrm{C}\left(\mathrm{kg} \cdot \mathrm{m}^{-3}\right)$ & 832.166 & 844.381 & 858.223 & 871.054 & 884.619 \\
\hline Cloud point $\left({ }^{0} \mathrm{C}\right)$ & -2.7 & -1.0 & 0.9 & 1.2 & 1.4 \\
\hline Pour point $\left({ }^{\circ} \mathrm{C}\right)$ & -6.9 & -6.5 & -6.7 & -6.5 & -6.8 \\
\hline Higher heating value $\left({\left.\mathrm{kJ} . \mathrm{kg}^{-1}\right)}^{-1}\right.$ & 45,280 & - & - & - & 39,004 \\
\hline
\end{tabular}

The viscosity of diesel- passion fruit biodiesel blends and passion fruit biodiesel was kept inside the limits established by the National Agency of Petroleum, Natural Gas and Biofuels - ANP $\left(3-6 \mathrm{~mm}^{2} \cdot \mathrm{s}^{-1}\right.$ at $\left.40^{\circ} \mathrm{C}\right)$. As expected, the increase of the percentage of the biodiesel at the diesel mixture leads to a rise at the mixture's viscosity, once the passion fruit biodiesel is more viscous than the diesel. This behavior was also reported by Souza et al. (2009), Mejia et al. (2013) and Geller et al. (2008). 
The diesel presented higher heating value of $45,280 \mathrm{~kJ} \mathrm{~kg}^{-1}$, and the passion fruit biodiesel, 39,004 $\mathrm{kJ} . \mathrm{kg}^{-1}$. Although the passion fruit biodiesel has revealed a higher heating value $13.86 \%$ smaller than the diesel, it has presented a good behavior when used in the motor pump set, not being noticed any anomaly at the motor operation.

\section{Energetic and exergetic analysis}

\section{Pump at the maximum speed}

The Tables 2 and 3 and Figures 2 and 3 show the useful work and the reversible work for diesel, diesel-passion fruit biodiesel mixtures and passion fruit biodiesel. The smaller flow rate condition implicated at a smaller useful work and reversible work. The pump was kept at maximum speed (3300 rpm).

Table 2: Useful work at maximum pump speed.

\begin{tabular}{|l|l|l|l|l|l|l|l|l|l|}
\hline Diesel & \multicolumn{3}{l}{ B25 } & \multicolumn{3}{l|}{ B50 } & B75 & \multicolumn{2}{l|}{ B100 } \\
\hline $\mathrm{m}^{3} / \mathrm{h}$ & $W_{u}(\mathrm{~kW})$ & $\mathrm{m}^{3} / \mathrm{h}$ & $W_{u}(\mathrm{~kW})$ & $\mathrm{m}^{3} / \mathrm{h}$ & $W_{u}(\mathrm{~kW})$ & $\mathrm{m}^{3} / \mathrm{h}$ & $W_{u}(\mathrm{~kW})$ & $\mathrm{m}^{3} / \mathrm{h}$ & $W_{u}(\mathrm{~kW})$ \\
\hline 12.26 & 2.066 & 11.98 & 1.915 & 12.30 & 2.268 & 12.14 & 2.100 & 12.24 & 2.097 \\
\hline 11.69 & 2.423 & 11.56 & 1.588 & 11.85 & 2.205 & 11.46 & 1.992 & 11.47 & 1.875 \\
\hline 10.22 & 1.261 & 9.89 & 1.857 & 9.76 & 2.063 & 9.91 & 2.117 & 9.64 & 1.915 \\
\hline 8.80 & 1.527 & 9.45 & 1.340 & 9.38 & 1.769 & 9.52 & 1.809 & 9.38 & 1.769 \\
\hline 7.17 & 1.636 & 7.95 & 1.606 & 8.20 & 1.466 & 8.37 & 1.700 & 8.26 & 1.666 \\
\hline 5.01 & 1.084 & 6.72 & 1.600 & 6.88 & 1.131 & 6.98 & 1.581 & 6.76 & 1.452 \\
\hline
\end{tabular}

Table 3: Reversible work at maximum pump speed.

\begin{tabular}{|l|l|l|l|l|l|l|l|l|l|}
\hline Diesel & B25 & B50 & B75 & B100 \\
\hline $\mathrm{m}^{3} / \mathrm{h}$ & $W_{\text {rev }}(\mathrm{kW})$ & $\mathrm{m}^{3} / \mathrm{h}$ & $W_{\text {rev }}(\mathrm{kW})$ & $\mathrm{m}^{3} / \mathrm{h}$ & $W_{\text {rev }}(\mathrm{kW})$ & $\mathrm{m}^{3} / \mathrm{h}$ & $W_{\text {rev }}(\mathrm{kW})$ & $\mathrm{m}^{3} / \mathrm{h}$ & $W_{\text {rev }}(\mathrm{kW})$ \\
\hline 12.26 & 0.557 & 11.98 & 0.444 & 12.30 & 0.463 & 12.14 & 0.462 & 12.24 & 0.449 \\
\hline 11.69 & 0.892 & 11.56 & 0.435 & 11.85 & 0.468 & 11.46 & 0.446 & 11.47 & 0.471 \\
\hline 10.22 & 0.435 & 9.89 & 0.419 & 9.76 & 0.408 & 9.91 & 0.445 & 9.64 & 0.402 \\
\hline 8.80 & 0.352 & 9.45 & 0.400 & 9.38 & 0.406 & 9.52 & 0.430 & 9.38 & 0.408 \\
\hline 7.17 & 0.387 & 7.95 & 0.360 & 8.20 & 0.371 & 8.37 & 0.392 & 8.26 & 0.376 \\
\hline 5.01 & 0.264 & 6.72 & 0.318 & 6.88 & 0.304 & 6.98 & 0.332 & 6.76 & 0.320 \\
\hline
\end{tabular}

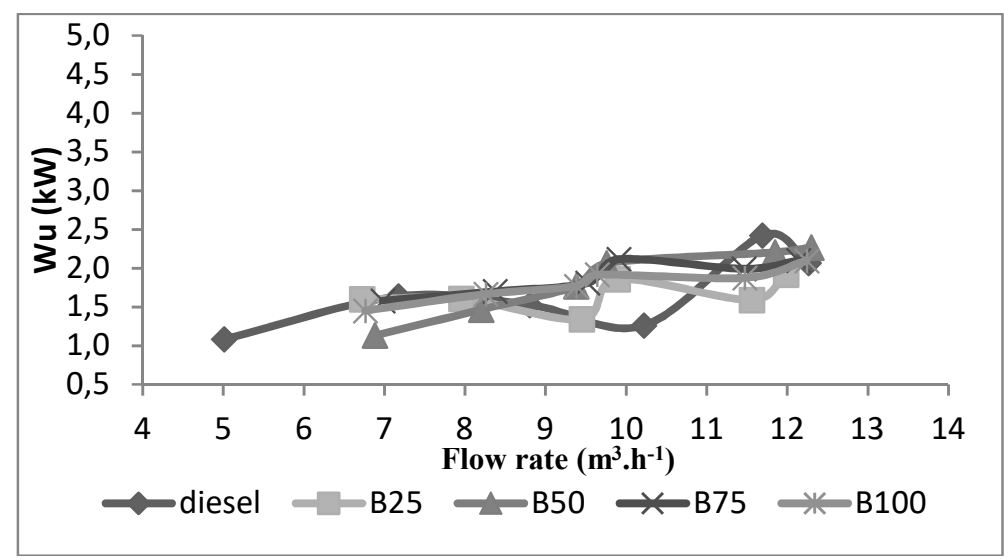

Figure 2 Useful work vs. flow rate, provided by the tested fuels at maximum pump speed 


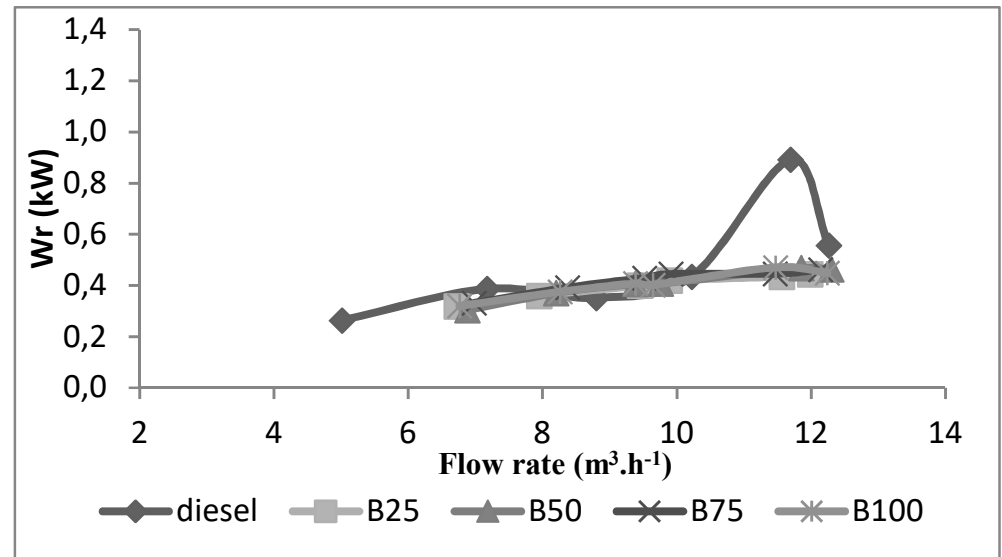

Figure 3 Reversible work vs. flow rate, provided by the tested fuels at maximum pump speed

\section{Pump at the maximum flow rate}

The Tables 4 and 5 and Figures 4 and 5 show the useful work and the reversible work for diesel, diesel-passion fruit biodiesel mixtures and passion fruit biodiesel. The smaller speed condition implicated at a smaller useful work and reversible work. The pump was kept at maximum flow rate.

Table 4: Useful work at maximum pump flow rate.

\begin{tabular}{|l|l|l|l|l|l|l|l|l|l|}
\hline Diesel & \multicolumn{3}{l}{ B25 } & B50 & B75 & \multicolumn{3}{l|}{ B100 } \\
\hline rpm & $W_{u}(\mathrm{~kW})$ & $\mathrm{rpm}$ & $W_{u}(\mathrm{~kW})$ & $\mathrm{rpm}$ & $W_{u}(\mathrm{~kW})$ & $\mathrm{rpm}$ & $W_{u}(\mathrm{~kW})$ & $\mathrm{rpm}$ & $W_{u}(\mathrm{~kW})$ \\
\hline 3299 & 2.066 & 3244 & 1.915 & 3255 & 2.268 & 3243 & 2.100 & 3234 & 2.097 \\
\hline 3122 & 1.681 & 3136 & 1.827 & 3147 & 1.988 & 3151 & 1.998 & 3156 & 1.711 \\
\hline 3054 & 1.451 & 3059 & 1.755 & 3038 & 1.770 & 3059 & 1.907 & 3057 & 1.530 \\
\hline 2986 & 1.438 & 2928 & 1.500 & 2953 & 1.580 & 2970 & 1.412 & 2930 & 1.285 \\
\hline 2882 & 1.270 & 2853 & 1.225 & 2866 & 1.392 & 2843 & 1.490 & 2856 & 1.263 \\
\hline 2725 & 1.056 & 2734 & 1.080 & 2773 & 1.342 & 2753 & 1.181 & 2722 & 0.958 \\
\hline
\end{tabular}

Table 5: Reversible work at maximum pump flow rate.

\begin{tabular}{|l|l|l|l|l|l|l|l|l|l|}
\hline Diesel & \multicolumn{3}{l}{ B25 } & B50 & B75 & \multicolumn{3}{l|}{ B100 } \\
\hline rpm & $W_{\text {rev }}(\mathrm{kW})$ & $\mathrm{rpm}$ & $W_{\text {rev }}(\mathrm{kW})$ & $\mathrm{rpm}$ & $W_{\text {rev }}(\mathrm{kW})$ & $\mathrm{rpm}$ & $W_{\text {rev }}(\mathrm{kW})$ & $\mathrm{rpm}$ & $W_{\text {rev }}(\mathrm{kW})$ \\
\hline 3299 & 0.557 & 3244 & 0.444 & 3255 & 0.463 & 3243 & 0.462 & 3234 & 0.449 \\
\hline 3122 & 0.503 & 3136 & 0.421 & 3147 & 0.391 & 3151 & 0.436 & 3156 & 0.404 \\
\hline 3054 & 0.449 & 3059 & 0.380 & 3038 & 0.363 & 3059 & 0.380 & 3057 & 0.390 \\
\hline 2986 & 0.412 & 2928 & 0.329 & 2953 & 0.344 & 2970 & 0.341 & 2930 & 0.341 \\
\hline 2882 & 0.385 & 2853 & 0.307 & 2866 & 0.327 & 2843 & 0.310 & 2856 & 0.330 \\
\hline 2725 & 0.313 & 2734 & 0.296 & 2773 & 0.310 & 2753 & 0.286 & 2722 & 0.304 \\
\hline
\end{tabular}

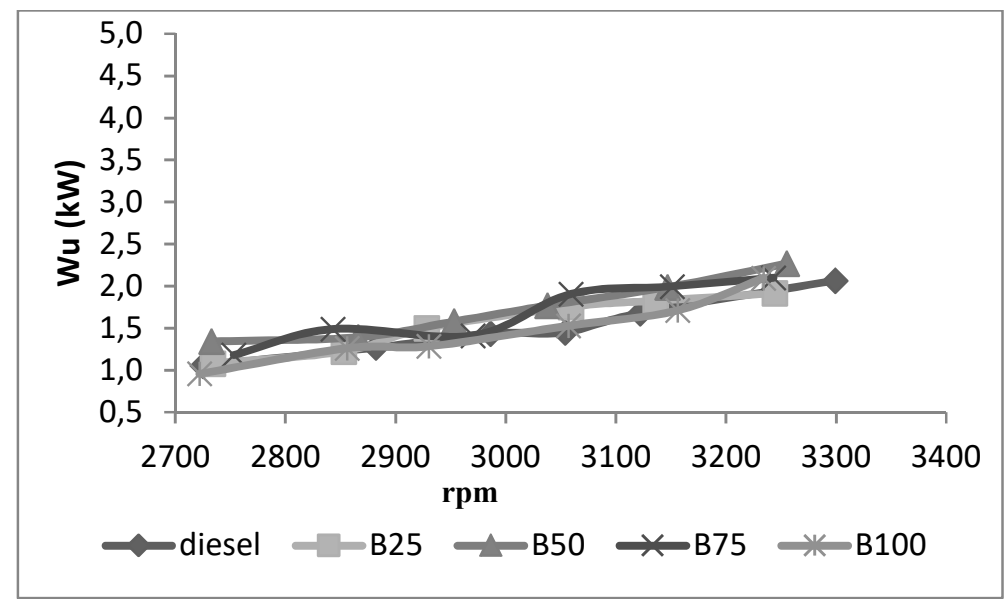

Figure 4: Useful work vs. speed, provided by the tested fuels at maximum pump flow rate. 


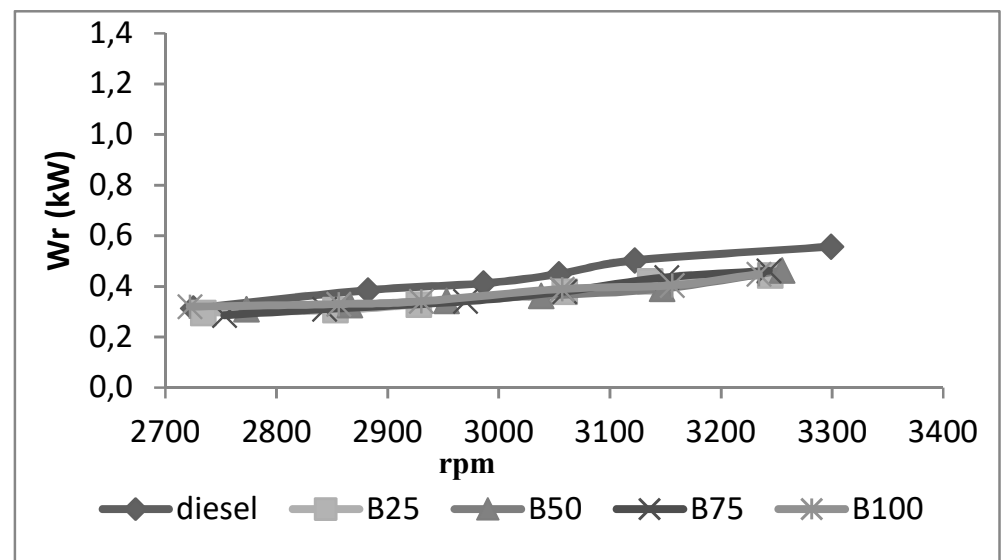

Figure 5 Reversible work vs. speed, provided by the tested fuels at maximum pump flow rate

\section{Efficiency of the Second Law of Thermodynamics}

The behavior of the efficiency of the second law as a function of flow rate, at maximum pump speed, is shown in Figure 6, for diesel, diesel-passion fruit biodiesel mixtures and passion fruit biodiesel. The efficiency ranges from $19.79 \%$ (B50 at $9.76 \mathrm{~m}^{3} / \mathrm{h}$ ) to $36.82 \%$ (diesel at $11.69 \mathrm{~m}^{3} / \mathrm{h}$ ). In the case of passion fruit biodiesel (B100), the efficiency range from $20.99 \%$, at $9.64 \mathrm{~m}^{3} / \mathrm{h}$ to $25.10 \%$, at $11.47 \mathrm{~m}^{3} / \mathrm{h}$. For the mixtures of passion fruit biodiesel with diesel, the maximum efficiency of the second law was $29.83 \%$ (B25 at 9.45 $\left.\mathrm{m}^{3} / \mathrm{h}\right)$.

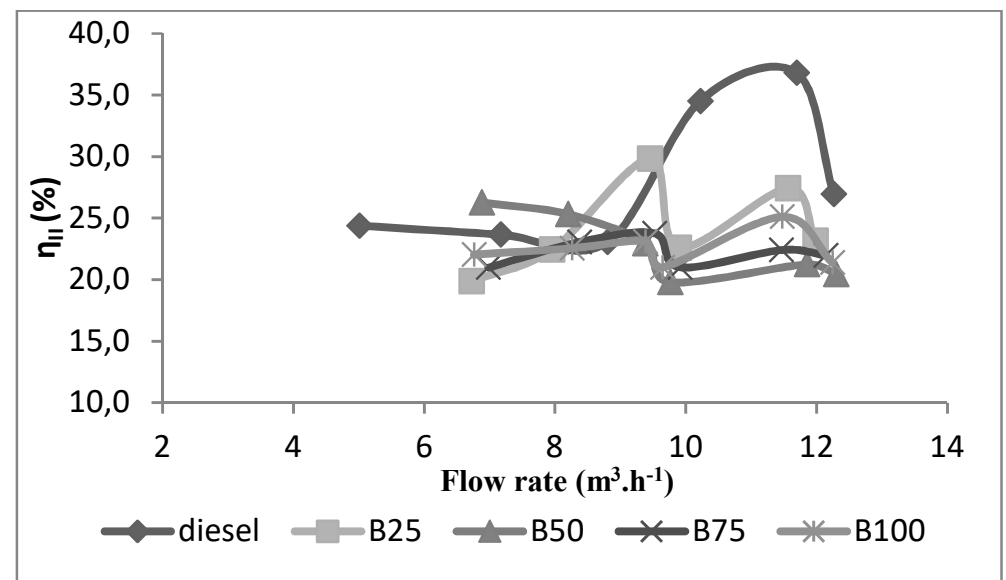

Figure 6 Second law efficiency vs. flow rate, provided by the tested fuels at maximum pump speed

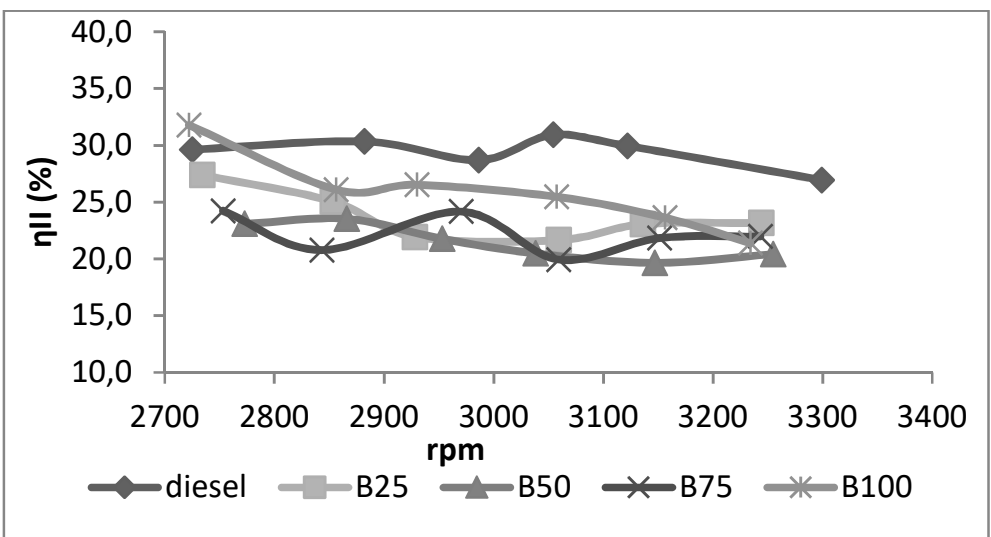

Figure 7 Second law efficiency vs. speed, provided by the tested fuels at maximum pump flow rate

The behavior of the efficiency of the second law as a function of pump speed, at maximum flow rate, is shown in Figure 7, for diesel, diesel-passion fruit biodiesel mixtures and passion fruit biodiesel. The 
efficiency ranges from 19.65\% (B50 at $3147 \mathrm{rpm}$ ) to $31.78 \%$ (B100 at $2722 \mathrm{rpm}$ ). For the mixtures of passion fruit biodiesel with diesel, the maximum efficiency of the second law was $27.39 \%$ (B25 at 2734 rpm).

\section{CONCLUSIONS}

The extracted oil from the passion fruit seeds constitutes a potential raw material for biodiesel production. The passion fruit biodiesel (B100) and different mixtures of passion fruit biodiesel with diesel can be used as fuel in a diesel engine in order to drive a centrifugal pump. In the case of the mixtures of passion fruit biodiesel with diesel, the B25 mixture, at maximum pump speed and the flow rate of $11.56 \mathrm{~m}^{3} / \mathrm{h}$, presented the maximum efficiency of the second law (29.83\%).

When the centrifugal pump operated at maximum flow rate, the maximum efficiency of the second law was $31.78 \%$ in the case of passion fruit biodiesel (B100), at $2722 \mathrm{rpm}$. The passion fruit biodiesel was produced from oil extracted from discarded seeds, becoming an alternative of economic interest for the biodiesel production.

ACKNOWLEDGMENTS: The author Roberto G. Pereira is grateful to the National Research Council of Brazil, CNPq, for the financial support.

\section{REFERENCES}

ARRUDA, T. B. M. G.; DANTAS, M. B.; ARAÚJO, K. C.; RODRIGUES, F. E. A.; RICARDO, N. M. P. S. S.; BITU, S. G.. Blends of diesel and biodiesel of cooking oil waste and moringa (Moringa ole' fera Lam): kinetic and thermal analysis and monitoring during storage. International Journal of Energy and Environmental Engineering, v.8, n.2, p.135-141, 2017. DOI: http://doi.org/10.1007/s40095-017$\underline{0232-x}$

ATABANI, A. E.; MOFIJUR, M.; MASJUKI, H. H.; BADRUDDIN, I. A.; CHONG, W. T.; CHENG, S. F.; GOUK, S. W.. A study of production and characterization of Manketti (Ricinodendron rautonemii) methyl ester and its blends as a potential biodiesel feedstock. Biofuel Research Journal, v.4, p.139146, 2014.

DEMIRBAS, A.. Biofuels securing the planet's future energy needs. Energy Conversion and Management, v.50, n.9, p.2239-2249, 2009. DOI: http://doi.org/10.1016/j.enconman.2009.05.010

FESTEL, G.; WÜRMSEHER, M.; RAMMER, C.; BOLES, E.; BELLOF, M.. Modelling production cost scenarios for biofuels and fossil Fuels in Europe. Journal of Cleaner Production, v.66, p.242-253, 2014. DOI:

http://doi.org/10.1016/j.jclepro.2013.10.038

FLÓREZ-ORREGO, D.; SILVA, J. A. M.; OLIVEIRA JR S.. Renewable and non-renewable exergy cost and specific $\mathrm{CO}_{2}$ emission of electricity generation: The Brazilian case. Energy Conversion and Management, v.85, p.619-629, 2014. DOI: http://doi.org/10.1016/i.enconman.2014.04.058

GELLER, D. P.; ADAMS, T. T.; GOODRUM, J. W.; PENDERGRASS, J.. Storage stability of poultry fat and diesel fuel mixtures: Specific gravity and viscosity. Fuel, v.87, n.1, p.92-102, 2008. DOI:

http://doi.org/10.1016/j.fuel.2007.03.043

KANOĞLU, M.; ÇENGEL, Y. A.; DINÇER, I.. Efficiency Evaluation of Energy Systems, SpringerBriefs in Energy, First ed. New York: Springer-Verlag, 2012.

KIST, B. B.; CARVALHO, C.; SANTOS, C. E.; TREICHEL, M.. Brazilian fruit year book. Santa Cruz do Sul: Gazeta Santa Cruz, 2018.

LÓPEZ, I.; QUINTANA, C. E.; RUIZ, J. J.; CRUZ-PERAGÓN, F.; DORADO, M. P.. Effect of the use of olive-pomace oil biodiesel/diesel fuel blends in a compression ignition engine: Preliminary exergy analysis, Energy Conversion and Management, v.85, p.227-233, 2014. DOI: http://doi.org/10.1016/j.enconman.2014.05.084

MACEDO, T. O.. Methodology for experimental exergetic evaluation of a pump driven by a diesel engine, operating with standard diesel and biodiesel. Dissertation (M.Sc.) Fluminense Federal University, 2013.

MEJIA, J. D.; SALGADO, N.; ORREGO, C. E.. Effect of blends of Diesel and Palm-Castor biodiesels on viscosity, cloud point and flash point. Industrial Crops and Products, v.43, p.791797, 2013. DOI:

http://doi.org/10.1016/i.indcrop.2012.08.026

PEIRÓ, L. T.; MÉNDEZ, G. V.; SCIUBBA, E.; DURANY, X. G.. Extended exergy accounting applied to biodiesel production. Energy, v.35, p.2861-2869, 2010. DOI: http://doi.org/10.1016/j.energy.2010.03.015 
PEREIRA, R. G.; TULCÁN, O. E. P.; FELLOWS, C. E.. Engine Performance: Biofuels versus Petrofuels. In: RIAZI, M. R.; CHIARAMONTI, D.. Biofuels Production and Processing Technology. CRC Press Taylor \& Francis Group, 2017a. p.569-586.

PEREIRA, R. G.; TULCÁN, O. E. P.; FELLOWS, C. E.; BRAZ, A. J. L.. Energy Generation and Exhaust Emissions Analysis in a Stationary Engine Using Palm Biodiesel, Palm Oil and Diesel. International Journal of Oil Gas and Coal Technology, v.16, n.4, p.402-421, 2017b. DOI:

http://doi.org/10.1504/IJOGCT.2017.087858

PEREIRA, R. G.; TULCAN, O. E. P.; FELLOWS, C. E.; SILVA, I. M.; SANTO FILHO, D. M. E.; LAMEIRA, V. J.; QUELHAS, O. L. G.. Energy generation using coconut biodiesel and coconut oil in a stationary engine, International Journal of Oil Gas and Coal Technology, v.7, n.4, p.450-473, 2014. DOI: http://doi.org/10.1504/IJOGCT.2014.062165

PEREIRA, R. G.; TULCAN, O. E. P.; FELLOWS, C. E.; LAMEIRA, V. J.; QUELHAS, O. L. G.; AGUIAR, M. E.; SANTO FILHO, D. M. E.. Sustainability and mitigation of greenhouse gases using ethyl beef tallow biodiesel in energy generation, Journal of Cleaner Production, v.29-30, p.269-276, 2012. DOI: http://doi.org/10.1016/j.jclepro.2012.01.007

PEREIRA, R. G.; OLIVEIRA, C. D.; OLIVEIRA, J. L.; OLIVEIRA, P. C. P.; FELLOWS, C. E.; PIAMBA, O. E.. Exhaust emissions and electric energy generation in a stationary engine using blends of diesel and soybean biodiesel. Renewable Energy, v.32, n.14, p.2453-2460, 2007. DOI: http://doi.org/10.1016/i.renene.2006.05.007
PUNOV, P.; EVTIMOV, T.; CHIRIAC, R.; CLENCI, A.; DANEL, Q.; DESCOMBES, G.. Progress in high performance, low emissions, and exergy recovery in internal combustion engines, International Journal of Energy Research, v.41, n.9, p.1229-1241, 2017. DOI: http://doi.org/10.1002/er.3666

REIFARTH, S.; TILLMARK, N.; ÅNGSTRÖM, H.. Exergy and energy analysis of high-pressure and low-pressure exhaust gas recirculation system of a diesel engine. International Journal of Exergy, v.17, n.3, p.313-334, 2015. DOI: http://doi.org/10.1504/IJEX.2015.070501

SOLIS, J. L.; BERKEMAR, A. L.; ALEJO, L.; KIROS, Y.. Biodiesel from rapeseed oil (Brassica napus) by supported $\mathrm{Li}_{2} \mathrm{O}$ and MgO, Int J Energy Environ Eng, v.8, n.1, p.9-23, 2017. DOI: http://doi.org 10.1007/s40095-016-0226-0

SOUZA, C. D. R; CHAAR, J. S.; SOUZA, R. C. R.; JEFFREYS, M. F.; SOUZA, K. S.; COSTA, E. J. C.; SANTOS, J. C.. Physicalchemical characterization of biodiesel and diesel binary mixtures marketed in Amazonas (in Portugues). Acta Amazônica, v.39, n.2, p.383-388, 2009.

TALENS, L.; VILLALBA, G.; GABARRELL, X.. Exergy analysis applied to biodiesel production. Resources, Conservation and Recycling, v.51, n.2, p.397-407, 2007. DOI: http://doi.org/10.1016/i.resconrec.2006.10.008

TIWARI, K.; GHOSH, P.; SARKAR, J.. Combined energy and exergy analysis of a corrugated plate heat exchanger and experimental investigation, International Journal of Exergy, v.15, n.4, p.395-341, 2014. DOI: http://doi.org/10.1504/IJEX.2014.066608

A CBPC - Companhia Brasileira de Produção Científica (CNPJ: 11.221.422/0001-03) detém os direitos materiais desta publicação. Os direitos referem-se à publicação do trabalho em qualquer parte do mundo, incluindo os direitos às renovações, expansões e disseminações da contribuição, bem como outros direitos subsidiários. Todos os trabalhos publicados eletronicamente poderão posteriormente ser publicados em coletâneas impressas sob coordenação da Sustenere Publishing, da Companhia Brasileira de Produção Científica e seus parceiros autorizados. Os (as) autores (as) preservam os direitos autorais, mas não têm permissão para a publicação da contribuição em outro meio, impresso ou digital, em português ou em tradução. 